Vorstand beschlossen, dass nach einer positiven Vorstandsentscheidung über die Ausrichtung eines Plenums die Jurorinnen und Juroren allein von der/den organisierenden Sektion/en bestimmt werden. Ausdrücklich wird schon jetzt darauf hingewiesen, dass trotz der Ausschreibung der Plenarvorschläge in einem Call for Papers die Jurorinnen bzw. Juroren mindestens einen Redner gezielt einladen können, vielleicht sollten.

Sämtliche Termine für die Ausschreibungen, die Plenarvorschläge, die Festlegung der Sektionssitzungen etc. werden in der Zeitschrift SOZIOLOGIE der DGS veröffentlicht werden. Jedoch wird schon jetzt gebeten, Anregungen, Vorschläge und Ideen an die Geschäftsstelle der DGS (dgs@mailbox.tu-dresden.de) zu senden.

Um Kontakt zu der lokalen Kongressorganisation aufzunehmen, wenden Sie sich bitte an Jörg Froharth, M.A., Universität Kassel, UniKasselTransfer / STARTnetz, Gottschalkstraße 22, D-34109 Kassel, Tel.: +49 (0)561 804-2498, Fax:+49(0)561804-7004, E-Mail: froharth@ uni-kassel.de.

\section{„The Quality of Social Existence in a Globalising World"}

XVI. World Congress of Sociology of the ISA (International Sociological Association), Durban, South Africa, July 23-29, 2006

The theme for the XVI ISA World Congress of Sociology is: „The Quality of Social Existence in a Globalising World“. With such a theme as its navigating principle, the Programme Committee is working hard to organize a number of exciting symposia for the semi-plenary morning sessions that will be of interest to the Association's members, research committees, thematic and working groups and national associations. Given also, the historic decision to hold such a Congress in Africa for the first time, a number of exciting sessions that raise continental issues of global concern are being finalized.

One of the most striking features of the Committee's experience was the enthusiastic support and ideas that have been received from the general membership as regards themes, sub-themes and special-sessions for the Congress. We thank you for that and we shall try and keep the dialogue going until the 12th hour.

What is pertinent now is to move on to the second cycle of our work. To do this we need to make you aware of the following approved dead- lines and to also ask you to start responding with the same energy as in the past.

Durban provides the international social science community with an opportunity to encounter a society in transition, in a context that is highly cognisant of the importance of social science in reconstruction and development. With its superb facilities and infrastructure, Durban has a proven track record of hosting international events and conferences.

Proposals for integrative sessions which involve at least 3 research committees, 3 national associations or a combination of the two, should be received at the ISA secretariat in Madrid until September 15th, 2005. Research committees, working and thematic groups, symposia and other programme coordinators should submit their programme of sessions to the congress secretariat in Durban (E-Mail: sociology2006@ ukzn.ac.za) and ISA Secretariat in Madrid (E-Mail: isa@cps.ucm.es) until January 31th, 2006. The deadline for electronic submission of abstracts of accepted papers to the Sociological Abstracts website http://www.csa.com/socioabs/ submit.html is March 31th, 2006. Only abstracts submitted by this web site will be accepted. In order to submit an abstract, a participant must have registered for the congress. Abstracts will be included in a print booklet to be distributed to registrants at the world congress. These abstracts will also be included in Sociological Abstracts.

For further information or registration please visit the website http://www.ucm.es/info/isa/ congress2006/index.htm.

Ari Sitas

(ISA Vice-President Programme,

University of KwaZulu Natal, South Africa)

\section{„Forschung mit dem Mikrozensus: Analysen zur Sozialstruktur und zum Arbeitsmarkt" \\ 4. Nutzerkonferenz \\ 12.-13. Oktober 2005, ZUMA, Mannheim}

Die inhaltlichen Schwerpunkte der MikrozensusNutzerkonferenz 2005 liegen auf bildungs- und genderspezifischen Aspekten des Arbeitsmarktes sowie den Potenzialen und möglichen Restriktionen des Mikrozensus als Datenquelle für die Analyse spezifischer sozialer Lagen. Im Vordergrund stehen zeitvergleichende Analysen. Daneben werden in den Beiträgen auch spezifische methodische Aspekte bei der Verwendung von Mikrozensusdaten in der Sozial- und Arbeits- 